\title{
Rodent Models of Experimental Autoimmune Uveitis
}

\author{
Rajeev K. Agarwal, Phyllis B. Silver, and Rachel R. Caspi
}

\begin{abstract}
The model of experimental autoimmune uveitis (EAU) in mice and in rats is described. EAU targets immunologically privileged retinal antigens and serves as a model of autoimmune uveitis in humans as well as a model for autoimmunity in a more general sense. EAU is a wellcharacterized, robust, and reproducible model that is easily followed and quantitated. It is inducible with synthetic peptides derived from retinal autoantigens in commonly available strains of rats and mice. The ability to induce EAU in various gene-manipulated, including HLAtransgenic, mouse strains makes the EAU model suitable for the study of basic mechanisms as well as in clinically relevant interventions.
\end{abstract}

\section{Keywords}

Uveitis; Uveoretinitis; EAU; Autoimmunity; T cells; Tolerance; Th1; Th2; IRBP; S-Ag

\section{Introduction}

Experimental autoimmune uveoretinitis (EAU) is an organ-specific, T-cell mediated autoimmune disease that targets the neural retina and related tissues that is induced by immunization with retinal antigens (1-3). The pathology of EAU closely resembles human uveitic diseases of a putative autoimmune nature in which patients display immunological responses to retinal antigens. Examples of such diseases, which have similar pathology to EAU and in which patients frequently have circulating lymphocytes that respond to retinal proteins, are sympathetic ophthalmia, birdshot retinochoroidopathy, Behcet's disease, and others $(4,5)$. In the United States alone, there are approximately 70,000 cases of uveitis per year, and autoimmune uveitis is estimated to account for approximately $10 \%$ of severe vision loss. Although none of the animal models mimics all the features of human disease, each has distinguishing characteristics that are reminiscent of different aspects of clinical uveitis. Although the retinal antigens that might be involved in human uveitis have not been definitively identified, many uveitis patients are seen to respond to the retinal soluble antigen ( $\mathrm{S}-\mathrm{Ag}=$ arrestin) and to a lesser extent to other retinal antigens. The EAU model has served as an invaluable tool to evaluate novel immunotherapeutic and conventional therapeutic strategies. The EAU model is also useful to study basic mechanisms of tolerance and autoimmunity to organ-specific antigens in immunologically privileged sites (5). Thus, EAU is useful as a tool for clinical as well as for basic studies of ocular and organ-specific autoimmunity.

EAU can be induced in susceptible animals by peripheral immunization with a number of evolutionarily well-conserved uveitogens (purified protein antigens extracted from the retina, or their peptides) in adjuvant or by adoptive transfer of lymphocytes specific to these antigens $(2,5,6)$. In many cases the sequence of these proteins is known and the pathogenic fragments have been identified. The majority of the studies have been performed using 
heterologous bovine antigens because autologous rat or mouse retinal proteins cannot be obtained in sufficient quantities. Uveitogenic retinal proteins are molecules whose homologues can be found as far down the phylogenetic scale as the invertebrates (7-9). The uveitogenic retinal proteins identified so far are:

1. The retinal soluble antigen (S-Ag, arrestin): This $48 \mathrm{kDa}$ intracellular photoreceptor protein is involved in the phototransduction cascade. It binds to photoactivatedphosphorylated rhodopsin, thereby apparently preventing the transducin-mediated activation of phosphodiesterase (10).

2. Interphotoreceptor retinoid-binding protein (IRBP): This $148 \mathrm{kDa}$ protein is found in the interphotoreceptor matrix, which helps in transporting Vitamin A derivatives between the photoreceptor and the retinal pigment epithelium (RPE). IRBP is composed of four evolutionary conserved homologous domains, which are thought to have arisen by gene duplication (8).

3. Rhodopsin, and its illuminated form, opsin: This $40 \mathrm{kDa}$ membrane protein is the rod visual pigment (7): Pathogenicity of this protein appears to be conformationdependent, as rhodopsin is more pathogenic than opsin (11).

4. Recoverin: This is $23 \mathrm{kDa}$ calcium-binding protein.

5. Phosducin: This is $33 \mathrm{kDa}$ soluble cytosolic photoreceptor protein.

Susceptibility to EAU is genetically controlled. It has been observed that different species, and strains within species, vary in their susceptibility. Thus, rats develop EAU after immunization with either S-Ag or IRBP. Guinea pigs are susceptible to S-Ag, but not to IRBP; and mice develop severe disease with IRBP, but not with S-Ag. Within each species there are susceptible and resistant strains. In mice and in rats both MHC and non-MHC gene control has been implicated $(12,13)$. MHC control is likely to be connected to the ability to bind and present uveitogenic epitopes. Non-MHC control is more complex and controlled by multiple genetic pathways that are not all defined. One important factor is the type of effector response that a given strain is genetically programmed to mount. Uveitis can be either Th17 or Th1 driven, and each of these effector T cell types is pathogenic when polarized in culture and infused into naïve mice (14). Strains that are naturally high Th1 and/ or Th17 responders such as C57BL/6 and B10.RIII tend to be susceptible, whereas strains that are overt Th2 responders (e.g., BALB/c mouse) tend to be resistant $(15,16)$.

Furthermore, skewing of the response towards a Th2-like phenotype, e.g., by treatment with the regulatory cytokines IL-4 and IL-10, can ameliorate EAU (17). Another factor is different level of expression of retinal antigens in the thymus, provoking efficient central tolerance to antigens expressed in "adequate" amounts (18). Other factors, including the hypothalamus pituitary adrenal (HPA) axis control, the number of mast cells in the eye, have also been implicated $(19,20)$. Genetic control of clinical and experimental uveitis has been reviewed (21).

Although in many clinical diseases and in some autoimmunity models there is a gender bias of susceptibility, in EAU there does not seem to be an obvious difference in susceptibility between males and females. However, reduced susceptibility is seen in pregnant females (22) and in animals harboring an active infection (Caspi et al., unpublished). Both these phenomena may be connected to the cytokine milieu elicited by the physiological state of the individual. Pregnant mice were found to have elevated TGF- $\beta$ levels (22) and infection elicits the production of IFN- $\gamma$, which has a protective role in tissue-specific autoimmunity, including EAU (23). There are no controlled studies of age-dependency of susceptibility. We have used animals between 6 weeks and 8 months of age, without any noticeable differences in disease development (Caspi et al., unpublished observations). 
EAU in many poorly susceptible strains can be enhanced by the treatment with Bordetella pertussis in the form of heat-killed bacteria or better yet, as purified pertussis toxin (PT), concurrently with immunization. This is similar to other autoimmune disease models, such as experimental autoimmune encephalomyelitis (EAE). Administration of PT concurrently with uveitogenic immunization permits expression of disease in resistant strains, and enhances it in susceptible strains $(15,24,25)$. The mechanism has for a long time been thought to involve the opening of the blood-organ barrier by PT $(26,27)$; however, recently we showed that a dominant effect of PT in EAU is to enhance the Th1 response and the Th17 response, both pathogenic in EAU $(15,24,28)$. This effect is at least in part due to maturation of dendritic cells by PT (16) and is mediated by the B subunit of PT (29). It is important to point out that PT can have strong inhibitory effects on disease as well if it is present at the time of cell migration to the target organ, due to its inhibitory effects on chemokine receptor signaling through G-protein inhibition (30). Therefore, not only the timing of PT administration, but also the amount administered, is important because excess PT administered at the time of immunization will persist into the effector stage of the disease and inhibit its expression (31).

EAU in mice and in rats induced with the different uveitogenic proteins or their peptides appears to share essentially the same immunological mechanisms and histological features; however, there are species-specific and strain-specific differences in the course of disease $(1,3,5,32,33)$. The type, number, and size of lesions serve as a basis for a semiquantitative grading system used to score disease severity. A degree of familiarity with ocular histology is needed to grade the disease in a specific fashion. In practice, disease scores assigned by different observers will not always be identical; however, when performed by the same person, grading should be consistent.

Although originally developed in the guinea pig, the two major EAU models in use today are the mouse and the rat. Each has its unique advantages. The mouse is immunologically well characterized and many congenic and gene-manipulated strains are available that permit sophisticated studies of basic immunological mechanisms. The rat's larger size permits therapeutic and surgical manipulations that are more difficult to do in the mouse and traditionally is the preferred model for endocrine and physiological studies. More specific attributes of EAU in the rat and mouse models are described ahead, under Subheading 3. EAU models in the guinea pig, the rabbit, and the monkey have been reviewed elsewhere (1, $5,34)$. The choice of model will therefore depend on the specific needs of the study.

The methods and descriptions ahead deal with the rat and the mouse models of EAU induced by defined synthetic peptides of retinal antigens. Synthetic peptides were chosen because they can be synthesized in every laboratory and do not require access to native retinal antigens from natural or recombinant sources.

\section{Materials}

1. Mice (B10.RIII and C57.BL/6) (Jackson Laboratories, Bar Harbor, ME).

2. Lewis rats (Charles River Laboratories, Wilmington, MA).

3. Pertussis Toxin (Catalog \#179A; List Biologicals, Campbell, CA).

4. IRBP and S-Ag peptides.

5. DMEM, RPMI-1640, HBSS (Hyclone Laboratories, Logan, UT).

6. L-glutamine, sodium pyruvate, nonessential amino acids, gentamycin (Invitrogen, Carlsbad, CA) as medium additives. 
7. Fetal bovine serum (FBS) (Hyclone).

8. Complete Freund's adjuvant (CFA) and Mycobacterium tuberculosis (Difco, Detroit, MI).

9. Purified Flt-3 ligand plasmid (pUMCV-mFLex containing the extracellular domain of murine fms-like tyrosine kinase 3 ligand; secreted form; National Gene Vector Laboratory, University of Michigan, Ann Arbor, MI).

10. Collagenase D (from Clostridium histolyticum) and DNase I (Roche, Nutley, NJ).

11. EDTA (Quality Biological, Inc., Gaithersburg, MD).

12. CD16/32, anti-CD40 monoclonal antibodies (BD Biosciences, San Jose, CA).

13. CD11c-conjugate magnetic beads (Miltenyi Biotec, Auburn, CA).

14. GM-CSF (Peprotech, Rocky Hill, NJ).

15. 12-Well tissue culture plates.

16. LPS (Escherichia coli 0111:B4, Sigma-Aldrich).

17. $4 \%$ Glutaraldehyde (Fisher Scientific, Fair Lawn, NJ) solution was prepared in phosphate buffered saline (PBS).

18. $10 \%$ neutral buffered formalin (Sigma-Aldrich).

19. Ophthalmic dilating solutions: $1 \%$ Tropicamide (Alcon Laboratories, Inc., Fort Worth, Tx) and phenylephrine hydrochloride; $2.5 \%$ (Bausch \& Lomb) for fundus examination procedure.

20. Sterile eye irrigating physiological solution (Ciba Vision Ophthalmics, Atlanta, GA).

\section{Methods}

\subsection{EAU in Rats}

The model of EAU, originally established in the guinea pig using homologous uveal tissue (35-37), was adapted to the rat in 1973 by Wacker and Kalsow (38) using whole retinal extracts, and was subsequently refined by de Kozak et al. using the retinal S-Ag (39). IRBP was shown to be uveitogenic in rats (40).

Susceptibility of EAU varies among different rat strains. The strain most commonly used for EAU studies is the Lewis rat. In the Lewis rat, the disease is of monophasic course, which develops characteristically severe uveitis and has served as a "standard" against which responses of other strains are compared. It appears that both MHC and non-MHC genes play a role (12), however, due to the limited availability of congenic and MHC-recombinant rat strains, their relative effects have not been well separated. Table 1 summarizes the susceptibility of some common inbred rat strains to EAU induced with the native S-Ag or IRBP. A more detailed list has been published elsewhere $(41,42)$.

The retinal proteins known as uveitogenic have historically been defined as such in the Lewis rat model, the most highly susceptible rat strain known. The normal dose is $30-50 \mu \mathrm{g}$ of S-Ag or IRBP, or 50-100 $\mu \mathrm{g}$ of rhodopsin emulsified in CFA. Lewis rats do not require PT as part of the immunization protocol to develop disease, but if used, PT will cause earlier onset and enhanced disease scores. The immunizing protocol of $30 \mu \mathrm{g}$ of peptide R16 of bovine IRBP (Table 2) in CFA normally results in disease onset on day 9 or 10. In contrast, immunization with $30 \mu \mathrm{g}$ of S-Ag in CFA usually results in onset between days 12 and 14 . Other strains may require PT as an additional adjuvant. Subcutaneous (s.c.) immunization in 
the thighs and base of tail with an emulsion of S-Ag or IRBP in CFA was as good or better for induction of disease as the footpad route (43).

Table 2 shows the commonly used epitopes that were found to be consistently pathogenic in the Lewis strain. The peptides which are pathogenic at low doses are considered to contain a major pathogenic epitope.

Induction of EAU in the Lewis rat by active immunization-As mentioned above, Lewis rat strain is highly susceptible to EAU. (In strains that are less susceptible, such as the F344, one must use PT as additional adjuvant and a higher dose of antigen is recommended.) Two peptides are recommended as being strongly and consistently uveitogenic in the Lewis: peptide R16 of bovine IRBP (residues 1,177-1,191, sequence ADGSSWEGVGVVPDV) and peptide S35 of human S-Ag (residues 341-360, sequence GFLGELTSSEVATEVPFRLM). S35 tends to cause stronger disease, but onset is a day or two later than R16.

1. Use 6-8 weeks old female Lewis rats, preferably housed in specific pathogen-free environment with food and water ad libitum. If rats are procured from an outside vendor, it is best to acclimate them for a few days before immunization.

2. Prepare an emulsion of the chosen peptide: $30 \mu \mathrm{g}$ of R16 or of S35, in CFA (1:1 v/ v) (Support Protocol 3.3.3) by sonication to provide $30 \mu \mathrm{g}$ of peptide in $200 \mu \mathrm{l} \mathrm{per}$ rat. Spin at $\sim 400 \times g$ to remove any air bubbles embedded in the emulsion. A wellprepared emulsion should have the consistency of thick cream.

3. A 16-G blunt-ended needle is used to draw the emulsion into a $1 \mathrm{ml}$ glass syringe preferable with a Luer Lock tip (rubber plungers in plastic syringes tend to soften and stick due to the oil in CFA). Carefully remove any residual air bubbles trapped in the syringe. Change the needle to a $23-\mathrm{G}$ needle and inject subcutaneously 100 $\mu \mathrm{l}$ at the base of the tail and $50 \mu \mathrm{l}$ in each thigh.

4. 7-9 days after immunization, start inspecting the eyes with a flashlight for loss of red reflex (Fig. 1). Grade the disease on a scale of 0 (no disease) to 4 (severe disease) based on the scoring method in Table 3.

5. Approximately 16 days after immunization (or at least 7 days after onset of the disease) euthanize the rats. Remove the eyes and process them for histopathology (Support Protocol 3.3.2).

6. Examine the hematoxylin and eosin-stained sections under a microscope and grade the disease histopathologically following the guidelines listed in Table 4.

Induction of EAU in the Lewis rat by adoptive transfer-EAU is a CD4+ T-cell mediated disease. The full histopathological picture can be obtained by adoptive transfer of immune lymph node or spleen cells or long-term CD4+, MHC class II-restricted T cell lines in the absence of detectable titers of serum antibodies $(2,44)$. The cells must be activated with antigen or mitogen just prior to transfer in order to efficiently mediate disease, suggesting that activation-dependent functions (lymphokine production, expression of adhesion molecules, etc.) are important. The minimal number of cells required to transfer the disease depends on their source and specificity $(2,44,45)$. The following protocol describes induction of disease using primary cultures of lymph node cells and peptide antigen.

1. Rats to be used as cell donors are immunized as mentioned in the active immunization protocol, above. The donor rats are sacrificed $10-12$ days post- 
immunization and draining lymph nodes (inguinal and iliac) are harvested and cultured with the immunizing peptide as follows.

2. Keep isolated lymph nodes in RPMI 1640 media containing $1 \%$ FBS or rat serum. Prepare single cell suspension by crushing the nodes using a plunger from a disposable plastic syringe on a sterile mesh in a Petri dish, with some sterile media to release the cells.

3. Transfer the cells to a $50 \mathrm{ml}$ centrifuge tube and wash the Petri dish with additional media. Spin the cells at $300 \times g$ and discard the supernatant. Resuspend the pellet in fresh media and repeat the washing procedure one to two times. Resuspend the final cell pellet in a small volume of RPMI 1640 media containing $1 \%$ FBS.

4. Count viable cells using an exclusion dye such as Trypan Blue.

5. Adjust the cell suspension to $5 \times 10^{6}$ cells $/ \mathrm{ml}$ by adding complete RPMI media (Support Protocol 3.3.4). Add the peptide used for immunization of the cell donors (R16 or S35) to a final concentration of $5 \mu \mathrm{g} / \mathrm{ml}$.

6. Distribute $2 \mathrm{ml}$ aliquots into 12 -well tissue culture plates and incubate the culture at $37^{\circ} \mathrm{C}$ for 3 days in $5 \%$ tissue $\mathrm{CO}_{2}$ incubator.

7. After $72 \mathrm{~h}$ collect, wash, and count the cells (as described above). All procedures are preferably done using RPMI 1640 media with $1 \%$ serum for maximal cell viability.

8. Inject $30-50 \times 10^{6}$ cells (in $0.3-0.5 \mathrm{ml}$ ) intraperitoneally into recipient Lewis rats.

9. Starting on day 3 after adoptive transfer, inspect the recipients for disease by examining the eyes with a flashlight for loss of red reflex (Fig. 1) and grade the disease as described in Table 3.

10. Between 11 and 14 days after adoptive transfer (around 7 days after disease onset), euthanize the rats, collect the eyes (Support Protocol 3.3.2) and process them for histopathological grading of EAU according to Table 4.

3.1.1. Expected Course of Disease-The course of disease in the Lewis rat is typically acute and of short duration. The time of onset will vary depending on severity of the developing disease, the antigen and the antigen dose. S-Ag and its peptides tend to give more severe disease but a later onset than IRBP and its peptides. For example, $30 \mu \mathrm{g}$ of S35 peptide in CFA without PT results in onset around day 12-14, while a similar dose of R16 in CFA without PT results in onset around day 10-12. If pertussis is used as additional adjuvant, the time of onset will be shortened by 2 days, and will usually be more uniform than without pertussis. The amount of antigen used to elicit disease can be reduced severalfold if PT is used. Onset of EAU induced by adoptive transfer is usually on day 4-7, i.e., about a week earlier than for active immunization. The active EAU in the Lewis rats lasts 12 weeks, and the disease does not relapse. The rapid onset and acute course of EAU in the Lewis rat makes it difficult to evaluate therapeutic intervention during active disease. Alternatively, to look at efferent-stage disease, begin intervention 7 days after immunization, when immune lymphocytes are already present, or to use an adoptive transfer system.

\section{Quantitation}

Clinical: Onset of disease in the albino Lewis rat can be recognized by inspecting the eyes with the aid of a good flashlight (Fig. 1). The normal eye appears translucent and reflects the light (red reflex). The first sign of uveitis is engorgement of blood vessels in the iris and an irregular pupil that cannot contract in response to light (caused by the iris adhering to the 
lens). Leukocyte infiltration and deposition of fibrin is first seen as dulling of the red reflex, progressing to complete opacification of the anterior chamber. The eye swells and can protrude from its socket (proptosis). In very severe cases hemorrhages in the anterior chamber and even perforation of the cornea can occur. In the latter case the animal should be euthanized. We grade clinical EAU on a scale of 0 (no disease) to 4 (severe disease), using the criteria listed in Table 3.

Histopathology: EAU is defined primarily as a posterior segment disease, because the target antigens reside in the retina. Lewis rats can develop very severe anterior chamber inflammation, which can lead to corneal perforation. Therefore, although clinical follow-up by anterior chamber inflammation is important and yields valuable information, the final readout should be recorded by histopathology. We grade EAU by histopathology based on number and extent of lesions on an arbitrary scale of 0 (none) to 4 (maximum severity), in half-point increments, as shown in Table 4 (42). Typical EAU vs. normal histology is shown in Fig. 2. Although the Figure shows EAU histopathology in the mouse, it is representative of what is seen in rat.

\subsection{EAU in Mice}

Mice are highly resistant to EAU induction with S-Ag, but some strains can develop severe EAU after immunization with IRBP (33). As in rats, age and sex do not appear to have a major influence on susceptibility to disease. Table 5 lists some common EAU susceptible mouse strains and IRBP epitopes that have been found to induce disease in each. The epitopes of the IRBP molecule pathogenic for the $\mathrm{H}-2^{\mathrm{b}}, \mathrm{H}-2^{\mathrm{r}}$, and $\mathrm{H}-2^{\mathrm{k}}$ haplotypes have been identified (46-48). In the B10.A mouse $\left(\mathrm{K}^{\mathrm{k}}, \mathrm{A}^{\mathrm{k}}, \mathrm{E}^{\mathrm{k}}, \mathrm{D}^{\mathrm{d}}\right)$ MHC control of susceptibility in mice has been tentatively mapped to the I-A region with modifying influences from the IE (13). In addition to a susceptible H-2 haplotype that can bind and present the uveitogenic epitopes, the strain must also have a "permissive" background to express disease. Studies with MHC-congenic mice showed that a nonpermissive background can completely prevent expression of disease in mice having a "susceptible" H-2. Known susceptible H-2 haplotypes include $\mathrm{H} 2^{\mathrm{r}}, \mathrm{H}-2^{\mathrm{k}}, \mathrm{H}-2^{\mathrm{a}}$ (shares class II subregion with $\mathrm{H}-2^{\mathrm{k}}$ ), H-2, $\mathrm{H}-2^{\mathrm{q}}$, and $\mathrm{H}-2^{\mathrm{d}}$. The last two, initially thought to be resistant, can in fact be shown to be EAUsusceptible in situations where IFN- $\gamma$ is neutralized or knocked out (ref. 23 and Grajewski and Caspi, unpublished).

The most susceptible mouse strain currently known is B10.RIII (H-2 ${ }^{r}$ (Table 5). Unlike other mouse strains, this strain does not require PT to develop disease by active immunization either with IRBP or with its major pathogenic epitope, residues 161-180 of human IRBP. Human epitopes 171-190 and 541-560 require PT, as does the murine sequence of peptide 161-180. This is likely due to thymic elimination of high-affinity $\mathrm{T}$ cells reacting with the endogenous version of peptide 161-180 (46). In less susceptible mouse strains, such as B10.A or C57BL/6, a higher dose of IRBP $(50-150 \mu \mathrm{g})$ or of the peptide appropriate for the haplotype in CFA is injected s.c., concurrently with PT (0.3-0.4 $\mu \mathrm{g})$ given i.p.

One of the strengths of the mouse model of EAU is the ready availability of many genemanipulated mouse strains. Knockouts and transgenics for various immunologically relevant genes have been, and continue to be, instrumental in unraveling the basic mechanisms in uveitis. EAU can be induced with human IRBP residues $1-20$ in mice of the $\mathrm{H}-2^{\mathrm{b}}$ haplotype, which is expressed by the C57BL/6 and 129 strains that typically serve for the production of transgenics and knockouts (46). More recently, additional epitopes that induce EAU in the $\mathrm{H}-2^{\mathrm{b}}$ haplotype, IRBP residues $171-190$ and $541-560$ have been identified (49). It is also important to mention here one newly established model, the "humanized" EAU model in 
HLA class II transgenic mice. Uveitic diseases in humans show strong associations with specific HLA class I or class II alleles, that vary depending on the disease and the population studied. The genetic associations in uveitis have recently been reviewed (21). MHC association strongly supports a role for antigen presentation by HLA molecules in the etiology of uveitis. HLA class I and class II transgenic mice afford a model to study these effects. Both HLA class I (A29) and class II transgenic mice (DR3, DR4, DR2, DQ6, DQ8) have been used to study uveitis. HLA A29 transgenics develop a spontaneous uveitis (50) whereas the various class II transgenic mice develop EAU after immunization with IRBP (51). Importantly, HLA-DR3 transgenic mice develop severe uveitis after immunization with S-Ag, which is thought to be involved in human uveitis, but which is not uveitogenic in wild type mice. These "humanized" models support an etiological role for retinal antigens, which are uveitogenic in animals, in human uveitis and validate use of the EAU model for the study of human disease.

Induction of EAU in the B10.RIII mouse by immunization-The following protocol is given for B10.RIII mice, the most susceptible mouse strain currently known. Human IRBP peptide 161-180 is used. This peptide does not require PT as part of the immunization protocol, although PT will promote more severe disease and an earlier onset (24). See ahead for a variation of the protocol for use in C57BL/6 mice.

1. Use 6-8 weeks old female B10.RIII mice $\left(\mathrm{H} 2^{\mathrm{r}}\right)$, preferably housed under specific pathogen-free conditions with food and water available ad libitum. If purchased from an outside vendor, let them acclimate to the animal facility for a few days before immunization.

2. Emulsify IRBP peptide $161-180$ (see sequence in Table 5) in CFA (1:1 v/v) by sonication to provide 10-25 $\mu \mathrm{g}$ peptide in $0.2 \mathrm{ml}$ emulsion per mouse. Severity of disease obtained will depend on the amount of peptide used (24). Spin at 2,000 rpm to remove air bubbles trapped in the emulsion. A well-prepared emulsion has the consistency of thick cream.

3. Use a 16-G blunt ended needle to draw the emulsion into a $1 \mathrm{ml}$ glass syringe with a Luer Lock tip (rubber plungers in plastic syringes tend to soften and stick due to the oil in CFA). Carefully remove any air bubbles trapped in the syringe. Change the needle to a $23-\mathrm{G}$ needle and inject each mouse subcutaneously with $0.2 \mathrm{ml}$ emulsion, dividing the dose among two thighs (50 $\mu \mathrm{l}$ each) and base of the tail (100 $\mu \mathrm{l})$.

4. 10-12 days post-immunization, monitor the eyes of these mice for disease induction by inspecting the fundus under a binocular microscope (Support Protocol 3.3.1). Grade the animals on a scale of 0 (no disease) to 4 (severe disease) using the criteria described in Table 6 and in Fig. 2.

5. Approximately 21 days after immunization (or 7 days after the disease onset), euthanize the mice and remove eyes for histopathology (Support Protocol 3.3.2).

6. Examine the hematoxylin and eosin-stained sections under a microscope and grade the disease histopathologically following the guidelines in Table 7 and in Fig. 3.

\section{Alternative protocol: Induction of EAU in the C57BL/ 6 mouse by immunization}

1. Use 6-8 weeks old female C57BL/6 mice $\left(\mathrm{H} 2^{\mathrm{b}}\right)$, preferably housed under specific pathogen-free conditions with food and water available ad libitum. If purchased from an outside vendor, let them acclimate to the animal facility for a few days before immunization. 
2. Emulsify human IRBP peptide $1-20$ (see sequence in Table 5$)$ in CFA $(1: 1 \mathrm{v} / \mathrm{v})$ by sonication to provide $200-300 \mu \mathrm{g}$ peptide in $0.2 \mathrm{ml}$ emulsion per mouse. Severity of disease obtained will depend on the amount of peptide used (46). Spin at 2,000 $\mathrm{rpm}$ to remove air bubbles trapped in the emulsion. A well-prepared emulsion has the consistency of thick cream.

3. Prepare pertussis toxin as adjuvant. Pertussis bacteria are not as potent as the purified toxin. Dilute stock to $3 \mu \mathrm{g} / \mathrm{ml}$ just before use in PBS or RPMI media with $1 \%$ syngeneic serum. Inject $0.1 \mathrm{ml}$ i.p. concurrently with the antigen emulsion. Alternatively, inject $0.2 \mu \mathrm{g}$ of PT on day 0 and $0.2 \mu \mathrm{g}$ again on day 2 (see ${ }^{\text {Notes }}$ ).

\section{Proceed as described above in the B10.RIII protocol starting from step 3.}

Notes: Although the EAU model is very robust, problems can arise with the technique at a number of levels. If no disease is obtained, the following questions should be considered (some may seem trivial or obvious, but we have encountered all!):

- Has the antigen been uveitogenic in previous experiments? If this is a new synthesis, a synthesis error might have changed the pathogenic epitope.

- Has a sufficient dose of antigen been used?

- Has the adjuvant been prepared correctly: enough mycobacteria, mixed before sampling (mycobacteria may have settled), well-prepared (thick) emulsion?

- Has the correct strain and substrain of mouse or rat been used? Substrains of the same strain, and even the same strain from a different vendor, may vary in their susceptibility.

- Are the animals in poor health? stressed? harboring an infection? Mice that are unhealthy, chronically stressed (have elevated corticosteroid levels) or actively infected (high levels of circulating interferon) will frequently fail to develop disease.

- Have the mice developed abscesses at the site of immunization (reaction to the mycobacteria in CFA) and were promptly treated by the facility vet with a nonsteroidal anti-inflammatory agent (NSAID) such as ibuprofen? NSAIDs may inhibit induction of disease.

Susceptibility varies with strain. For some commonly used mouse strains immunized with IRBP, hierarchy of susceptibility is B10.RIII > B10.A = B10.BR > C57BL/10 > C57BL/6 2129 .

Chronic exposure to strong light can damage photoreceptor cells and cause retinal degeneration. Albino animals are especially sensitive to this due to lack of pigment in their eyes. For this reason, it is important to protect animals that will be used in EAU experiments from strong light, as the resulting retinal damage may confound correct EAU assessment. This includes frequent and prolonged fundoscopies.

Some common laboratory mouse strains carry the retinal degeneration1 mutation $(r d l)$ and congenitally lack photoreceptor cells. These strains are of course not appropriate for EAU studies, as they do not possess the target tissue. Strains carrying the $r d 1$ gene include FVB/N, CBA, SLJ/J, PL/J, and most C3H substrains. However, F1 hybrids of these strains with a sighted strain such as B10.RIII or C57BL/6 will be sighted. As determined by crosses between sighted strains, a hybrid's susceptibility is usually intermediate between the two parental strains. Of note, recently it was reported that the C57BL/6N mouse substrain (but not C57BL/ $6 \mathrm{~J}$ ), carry the $r d 8$ mutation (70). This retinal degeneration phenotype is more subtle and does not completely destroy the retina, but its impact on EAU susceptibility has not been determined.

If a strain other than B10.RIII, or a B10.RIII hybrid with a less susceptible strain is being used, pertussis toxin may be needed. Because the activity and toxicity of PT varies among vendors and product lots, it is advisable to perform a dose response trial with the reagent before proceeding to the actual experiment. Animal deaths after immunization are usually associated with PT administration. Immunize groups of mice with the IRBP peptides and inject several doses of PT in a range between $0.2 \mathrm{and} 0.5 \mu \mathrm{g} / \mathrm{mouse}$. Choose a dose that results in moderate to high disease without toxicity. Splitting the PT administration into two low doses on day 0 and day 2 is an alternative protocol. To alleviate stress to the animals after immunization, it is helpful to add DietGel ${ }^{\mathrm{TM}}$ (PharmaServ, Framingham, MA) to the bottom of the cages to provide them with easy access to hydration and nutritional support. The PT dose for rats can be approximately doubled that for mice.

When anesthetizing animals for any reason, including fundoscopy, it is important to keep in mind that anesthetized animals sleep with their eyes open and do not blink. Therefore, if animals are going to be asleep for more than just a few minutes, it is necessary to place an ointment on the eyes to prevent drying of the cornea. Drying of the eyes will inevitably result in exposure keratitis, which will cause corneal opacification and will make follow-up of clinical disease difficult or impossible.

Notes on fundoscopy: fundoscopy is best done under general anesthesia. With some practice, fundoscopy can be performed on nonanesthetized animals, but if disease is borderline or severity scores are to be assigned, it advisable to lightly anesthetize the mouse prior to fundoscopy to facilitate a more thorough inspection. Note: the dilating drops cause a temporary opacification of the lens within 5-10 min after application, so it is important to complete the fundoscopy within that time frame.

Notes on histopathology: When cutting the embedded eye tissue, it is important to make sure that the cut is made through the pupillary-optic nerve plane. If the inflammation is mild, pathology is often most apparent around the optic nerve head. Therefore, if sections are cut more laterally, it can be missed. Especially in mild cases, specimens positive on fundoscopy may appear to be negative on histology due to the fact that pathology is focal and the sectioning may have missed it. Therefore, it is important to prepare and examine several nonconsecutive sections. 
Induction of EAU in B10.RIII or C57BL/6 mice by adoptive transfer-Adoptive transfer of primed uveitogenic effector cells, just like in rats, can induce EAU in mice. Primary cultures from immunized donors, as described in the protocol ahead, can be used as a source of effector cells. If desired, the cells may be polarized to Th1 or Th17 phenotype using published methods before adoptive transfer $(52,53)$. Alternatively, long-term antigenspecific $\mathrm{T}$ cell lines, which are typically CD4+ cells of the Th1 phenotype, can be derived from draining lymph-node cells of IRBP- or peptide-immunized mice (48).

1. Immunize donor mice as described above, using peptide 161-180 of human IRBP for B10.RIII mice and peptide 1-20 of human IRBP for C57BL/6 mice.

2. After 10-14 days, harvest draining lymph nodes (inguinal and iliac) as well as spleens from donor mice.

3. Place isolated lymph nodes and spleens in DMEM media containing $1 \%$ FBS or mouse serum. Prepare a single cell suspension (lymph nodes and spleen) by disrupting the spleens and the lymph nodes using a sterile rubber plunger from a disposable plastic syringe on a sterile mesh in a Petri dish with some sterile media to release the cells.

4. Pool the suspensions of lymph node cells and splenocytes and transfer to $50 \mathrm{ml}$ centrifuge tubes. Wash the cells by centrifuging at $300 \times g$. Discard the supernatant and resuspend the pellet in fresh media. Repeat the washing one to two times. Resuspend the final cell pellet in a small volume of DMEM media containing $1 \%$ serum to maintain maximal viability of the cells.

5. Take a small aliquot and count the viable cells using a vital dye such as Trypan Blue.

6. Adjust the cell concentration to $10 \times 10^{6}$ live cells $/ \mathrm{ml}$ in complete DMEM media (Support Protocol 3.3.4) containing 20-25 $\mu \mathrm{g} / \mathrm{ml}$ of the immunizing peptide. Optional: including $5 \mathrm{ng} / \mathrm{ml}$ of IL-12 in the culture will result in a more highly Th1polarized population that will transfer disease with fewer cells (46).

7. Distribute $150 \mathrm{ml}$ aliquots into $175-\mathrm{cm}^{2}$ tissue culture flasks and incubate for 3 days in a humidified $37^{\circ} \mathrm{C}$ tissue incubator with $10 \% \mathrm{CO}_{2}$.

8. Important: After $24 \mathrm{~h}$ and again after $48 \mathrm{~h}$ of culture, bring the nonadherent cells into suspension by gently rocking the flasks and transfer the entire suspension to a new flask of the same size. This gets rid of excess (adherent) macrophages that produce inhibitory factors.

9. After $72 \mathrm{~h}$ of culture, collect, wash, and count the viable cells. There usually are many dead cells in the culture at that point. Purifying the cells by centrifugation over Ficoll (Lympholyte M, Accurate Biochemicals) can help obtain a more pure population of live cells and facilitate counting. Suspend the counted cells in DMEM media with $1 \%$ normal mouse serum.

10. Inject cells intraperitoneally into syngeneic recipients in a volume of $0.5 \mathrm{ml}$ or less. For B10.RIII mice, inject 30-50 × $10^{6}$ cells. For recipient C57BL/6 mice, inject $50-100 \times 10^{6}$ cells. If IL-12 is used during culture, this number may be reduced.

11. Starting 4 days after adoptive transfer, inspect the recipients for disease induction by fundus examination (see Support Protocol 3.3.1 and Fig. 2).

12. Between 12 and 14 days after adoptive transfer (at least 7 days after disease onset), euthanize the mice, collect the eyes, and process them for histopathology. Score the eyes according to the criteria listed in Table 7 and Fig. 3. 
Induction of EAU in B10.RIII mice by antigen-pulsed dendritic cells-The following is a recently described protocol to induce EAU in B10.RIII mice by the injection of matured dendritic cells loaded with peptide 161-180 (DC-EAU) (54):

1. Use 6-8-week-old female B10.RIII mice, preferably housed under specific pathogen-free conditions with food and water available ad libitum. If purchased from an outside vendor, let acclimatize to the animal facility for a few days before immunization.

2. To increase the number of functional DCs in vivo, a single injection of $50 \mu \mathrm{g}$ of Flt-3 ligand DNA was delivered by the hydrodynamic protocol described by Knapp and Liu (55).

3. Harvest spleen 7 days later and prepare single-cell suspension following Support Protocol 3.3.5.

4. Block cells with Fc receptor Ab, CD16/CD32. Add anti-CD11c-conjugated magnetic beads and purify the $\mathrm{CD} 11 \mathrm{c}^{+}$population according to the manufacturer's directions. Run the "possel" separation program. Check the purity of the CD11 $\mathrm{c}^{+}$ cell population by flow cytometry.

5. Suspend the purified $\mathrm{CD} 11 \mathrm{c}^{+}$cells in complete medium for cell culture (see Support Protocol 3.3.4) substituting $1 \%$ fresh-frozen mouse serum for the FBS, and adding $10 \mathrm{ng} / \mathrm{ml} \mathrm{GM-CSF}$. Deliver $2 \times 10^{6}$ cells in $1 \mathrm{ml}$ aliquots into 12 -well plates. Allow to adhere for $1 \mathrm{~h}$ at $37^{\circ} \mathrm{C}$.

6. Rinse wells $2 \times$ with media in order to remove nonadherent cells.

7. To mature the DC deliver complete medium (step 5) additionally supplemented with $100 \mu \mathrm{g} / \mathrm{ml}$ peptide $161-180,1 \mu \mathrm{g} / \mathrm{ml}$ LPS, and $5 \mu \mathrm{g} / \mathrm{ml}$ anti-CD40. Incubate $4.5 \mathrm{~h}$ at $37^{\circ} \mathrm{C}$.

8. Harvest DC and wash twice with HBSS containing $1 \%$ normal mouse serum.

9. Inject one to two million DC s.c. into one footpad of recipient mice (day 0). Inject 0.3-0.4 $\mu$ g PT i.p. on day 2. Repeat injection with fresh in vitro matured DC on day 4 (See induction regimen, Fig. 3).

10. EAU evaluation by fundus exam or histology is performed on day 18 .

3.2.1. Expected Course of Disease-The severity and clinical course of EAU induced by active immunization (CFA-EAU) with peptide 161-180 in B10.RIII mice is typically monophasic, resembling the Lewis rat, and lasts for $2-3$ weeks. High intensity immunization results in an acute form of disease with onset as early as day 8 or 9 and widespread photoreceptor damage, whereas lower intensity of immunization will result in milder disease with progressively later onset (24). In other strains (e.g., B10.A) it is possible to observe relapsing disease after a low to intermediate intensity protocol (56). As in the Lewis, the rapid onset and acute course of EAU induced with peptide 161-180 in B10.RIII mice makes it difficult to evaluate therapeutic intervention during active disease. Alternatively, to look at efferent-stage disease, begin intervention 7 days after immunization, when immune lymphocytes are already present, or to use an adoptive transfer system.

Interestingly, the DC-EAU model exhibits unique clinical manifestations and inflammatory characteristics when compared to traditional CFA-induced EAU. DC-EAU is less severe, of shorter duration, and is characterized by focal infiltrates and short linear lesions. While the cellular infiltrate of CFA-EAU is composed of monocytes and lymphocytes, DC-EAU is largely granulocytic with a small population of eosinophils. Intraocularly, IFNY predominates in DC-EAU with little or no detectable IL-17, i.e., a dominant Th1 response. 
In contrast, the eye milieu of CFA-EAU consists of a combination of IFNy, IL-17, and IL-18, i.e., a mixed Th1/Th17 response. The differences observed in these two EAU models highlights the variability of clinical and immunological outcomes when the same antigen is processed in the context of distinct innate stimuli. The DC-EAU induction system can offer the investigator an opportunity to choose a disease model that is devoid of IL-17 influence, has a milder outcome, and is free of prolonged innate stimulation generated by the $\mathrm{Ag} / \mathrm{CFA}$ depot.

\section{Quantitation}

Clinical: Unlike rats, in susceptible strains of mice (B10 background), black pigmentation of the eyes and an often mild involvement of the anterior chamber preclude detection of disease by anterior chamber examination. However, in pigmented strains it is possible to observe changes in the fundus of the eye under a binocular microscope after dilating the pupil (Support Protocol 3.3.1) (4). Visualization of the fundus is possible if the anterior chamber does not become infiltrated with cells, or after the infiltrate clears (usually within a few days after onset). The nature, number, and severity of the lesions are used as criteria for clinical scoring, on a scale of 0 (no change) to 4 (severe disease) (Table 6).

Histopathology: Histological grading is the final readout of the disease and is performed on methacrylate-embedded tissue sections (Support Protocol 3.3.2). Disease is scored on a scale of 0 (no disease) to 4 (maximum disease) in half-point increments, according to a semiquantitative system described earlier (33). Examples of various grades of pathology are shown in Fig. 2.

\subsection{Support Protocols}

3.3.1. Fundoscopic Examination-Fundoscopic examination can be used to detect and evaluate EAU in pigmented animals, provided that the anterior segment of the eye remains clear. In this procedure, retina of the eye is examined through the dilated pupil under a microscope. Fundoscopy is a good tool for determining the onset and clinical grading of disease in pigmented animals but not in albinos.

\section{Materials}

Ophthalmic dilating solutions: $1 \%$ Tropicamide and Phenylephrine.

Sterile physiological solution (either normal saline or PBS or artificial tears).

Binocular microscope with coaxial illumination.

Microscope coverslip

Anesthetize the animals and dilate the pupil with one to two drops of dilating solution. It takes several minutes for the medication to take effect. Place a drop of sterile physiological solution and a microscope coverslip on the cornea to equalize refraction. Manipulate the head of the mouse under the microscope to inspect as far up the sides of the retina as possible. Look for engorged blood vessels, constricted blood vessels ("cuffing"), white linear lesions, subretinal hemorrhages, and retinal detachment. Typical appearance of a uveitic fundus is shown in Fig. 4.

3.3.2. Handling of Eyes for Histopathology-Eyes should be collected within $15 \mathrm{~min}$ of euthanasia; otherwise, autolysis may preclude correct evaluation of the results. Enucleation in rats should be performed by carefully dissecting the globe from the periocular tissues and the optic nerve without applying pressure on the globe, to avoid maceration of delicate ocular tissues that become even more fragile when inflamed. In mice 
for enucleation, the eye should be made to protrude by applying pressure on the skull, and plucked free of the tissue with a curved forceps.

Freshly enucleated eyes are fixed in $4 \%$ phosphate-buffered glutaraldehyde for $1 \mathrm{~h}$ and then transferred into $10 \%$ phosphate-buffered formalin at least overnight or until processing. The brief fixation in $4 \%$ glutaraldehyde prevents artifactual detachment of the retina from the choroid. However, leaving the eyes in glutaraldehyde for too long will cause excessive hardening of the lens, which will make sectioning difficult. The grading is conveniently done on methacrylate or paraffin-embedded tissue sections cut up to $8 \mu \mathrm{m}$ in thickness, stained with hematoxylin and eosin. To arrive at the final grading, several sections cut through the pupillary-optic nerve axis should be examined for each eye. It should be remembered that in this type of visual scoring, there is always an element of subjectivity. Therefore, it is important that the results be read in a masked fashion, preferably always by the same person. Whenever possible, both eyes should be evaluated for the disease, as disease may be unilateral. If it becomes experimentally necessary to take only one eye, always collect the same eye to average out this random variation.

3.3.3. Complete Freund's Adjuvant $-100 \mathrm{mg}$ heat killed M. tuberculosis (strain H37Ra; Difco) is crushed into a fine powder using a porcelain mortar and pestle. Mix with $70 \mathrm{ml}$ of CFA $\left(1.0 \mathrm{mg} / \mathrm{ml}\right.$ of $M$. tuberculosis). Store at $4{ }^{\circ} \mathrm{C}$ until used. The suspension must be thoroughly mixed before each use as the mycobacterial particles settle quickly to the bottom.

\subsubsection{Complete Medium for Cell Culture (RPMI 1640 or DMEM)}

$500 \mathrm{ml}$ bottle of RPMI 1640 or DMEM.

$50 \mathrm{ml} \mathrm{FBS} \mathrm{(10 \%} \mathrm{final).}$

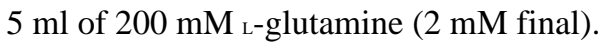

$5 \mathrm{ml}$ of $100 \mathrm{mM}$ Sodium pyruvate ( $1 \mathrm{mM}$ final).

$5 \mathrm{ml}$ of $10 \mathrm{mM}$ Nonessential amino acids $(0.1 \mathrm{mM}$ final).

$0.5 \mathrm{ml}$ of $50 \mathrm{mg} / \mathrm{ml}$ Gentamycin $(50 \mu \mathrm{g} / \mathrm{ml}$ final $)$.

$0.05 \mathrm{ml}$ of $0.5 \mathrm{M} 2$-mercaptoethanol (5 $\mu \mathrm{M}$ final).

Filter through $0.2 \mu \mathrm{m}$ and store up to 4 weeks at $4{ }^{\circ} \mathrm{C}$.

\subsubsection{Preparation of a Single-Cell Suspension of Splenocytes-Single-cell} suspension preparation of splenocytes follows the protocols of Bjorck (57) and Vremec et al. (58) with modifications. Briefly, mince the spleen into small fragments and digest in $10 \mathrm{ml}$ complete media (Support Protocol 3.3.4) supplemented with $1.0 \mathrm{mg} / \mathrm{ml}$ collagenase D and DNase I for $45 \mathrm{~min}$ at $37^{\circ} \mathrm{C}$ with frequent shaking. One milliliter of $0.1 \mathrm{M}$ EDTA is then added to break the DC-T cell complexes. Continue shaking for $5 \mathrm{~min}$. Pass tissue through a 70- $\mu \mathrm{M}$ nylon cell strainer (BD Falcon) and centrifuge. Lyse red blood cells, wash, and then suspend in culture media.

\section{References}

1. Caspi, RR. Basic mechanisms in immune-mediated uveitic disease. In: Lightman, SL., editor. Immunology of eye disease. Vol. Ch. 5. Kluwer Academic Publishers; Lancaster, UK: 1989. p. 61-86. 
2. Caspi RR, Roberge FG, McAllister CG, el Saied M, Kuwabara T, Gery I, Hanna E, Nussenblatt RB. $\mathrm{T}$ cell lines mediating experimental autoimmune uveoretinitis (EAU) in the rat. J Immunol. 1986; 136:928-933. [PubMed: 2416842]

3. Gery, I.; Robinson, WG., Jr; Shichi, H.; El-Saied, M.; Mochizuki, M.; Nussenblatt, RB.; Williams, RM. Differences in susceptibility to experimental autoimmune uveitis among rats of various strains. In: Chandler, JW.; O’Conner, GR., editors. Advances in immunology and immunopathology of the eye; Proceedings of the third international symposium on immunology and immunopathology of the eye; NY: Masson Publishing; 1985. p. 242-245.

4. Nussenblatt, RB.; Whitcup, SM.; Palestine, AG. Uveitis: fundamentals and clinical practice. 2. Mosby - Year Book, Inc.; St. Louis, MO: 1996.

5. Gery I, Mochizuki M, Nussenblatt RB. Retinal specific antigens and immunopathogenic processes they provoke. Prog Retinal Res. 1986; 5:75-109.

6. Sanui H, Redmond TM, Kotake S, Wiggert B, Hu LH, Margalit H, Berzofsky JA, Chader GJ, Gery I. Identification of an immunodominant and highly immunopathogenic determinant in the retinal interphotoreceptor retinoid-binding protein (IRBP). J Exp Med. 1989; 169:1947-1960. [PubMed: 2471769]

7. Applebury ML, Hargrave PA. Molecular biology of the visual pigments. Vision Res. 1986; 26:1881-1895. [PubMed: 3303660]

8. Borst DE, Redmond TM, Elser JE, Gonda MA, Wiggert B, Chader GJ, Nickerson JM. Interphotoreceptor retinoid-binding protein. Gene characterization, protein repeat structure, and its evolution. J Biol Chem. 1989; 264:1115-1123. [PubMed: 2910846]

9. Mirshahi M, Boucheix C, Collenot G, Thillaye B, Faure JP. Retinal S-antigen epitopes in vertebrate and invertebrate photoreceptors. Invest Ophthalmol Vis Sci. 1985; 26:1016-1021. [PubMed: 2409049]

10. Pfister C, Chabre M, Plouet J, Van Tuyen V, De Kozak Y, Faure JP, Kühn H. Retinal S antigen identified as the $48 \mathrm{~K}$ protein regulating light-dependent phosphodiesterase in rods. Science. 1985; 228:891-893. [PubMed: 2988124]

11. Schalken JJ, Winkens HJ, van Vugt AH, Bovëe-Geurts PH, de Grip WJ, Broekhuyse RM. Rhodopsin-induced experimental autoimmune uveoretinitis: dose-dependent clinicopathological features. Exp Eye Res. 1988; 47:135-145. [PubMed: 2970396]

12. Hirose S, Ogasawara K, Natori T, Sasamoto Y, Ohno S, Matsuda H, Onoe K. Regulation of experimental autoimmune uveitis in rats-separation of MHC and non-MHC gene effects. Clin Exp Immunol. 1991; 86:419-425. [PubMed: 1747950]

13. Caspi RR, Grubbs BG, Chan CC, Chader GJ, Wiggert B. Genetic control of susceptibility to experimental autoimmune uveoretinitis in the mouse model: Concomitant regulation by MHC and non-MHC genes. J Immunol. 1992; 148:2384-2389. [PubMed: 1560198]

14. Luger D, Silver PB, Tang J, Cua D, Chen Z, Iwakura Y, Bowman EP, Sgambellone NM, Chan CC, Caspi RR. Either a Th17 or a Th1 effector response can drive autoimmunity: conditions of disease induction affect dominant effector category. J Exp Med. 2008; 205:799-810. [PubMed: 18391061]

15. Caspi RR, Silver PB, Chan CC, Sun B, Agarwal RK, Wells J, Oddo S, Fujino Y, Najafian F, Wilder RL. Genetic susceptibility to experimental autoimmune uveoretinitis in the rat is associated with an elevated Th1 response. J Immunol. 1996; 157:2668-2675. [PubMed: 8805672]

16. Sun B, Rizzo LV, Sun SH, Chan CC, Wiggert B, Wilder RL, Caspi RR. Genetic susceptibility to experimental autoimmune uveitis involves more than a predisposition to generate a $\mathrm{T}$ helper-1-like or a T helper-2-like response. J Immunol. 1997; 159:1004-1011. [PubMed: 9218623]

17. Rizzo LV, Xu H, Chan CC, Wiggert B, Caspi RR. IL-10 has a protective role in experimental autoimmune uveoretinitis. Int Immunol. 1998; 10:807-814. [PubMed: 9678762]

18. Egwuagu CE, Charukamnoetkanok P, Gery I. Thymic expression of autoantigens correlates with resistance to autoimmune disease. J Immunol. 1997; 159:3109-3112. [PubMed: 9317106]

19. Caspi RR, Chan C-C, Fujino Y, Oddo S, Najafian F, Bahmanyar S, Heremans H, Wilder RL, Wiggert B. Genetic factors in susceptibility and resistance to experimental autoimmune uveoretinitis. Curr Eye Res. 1992; 11(suppl):81-86. [PubMed: 1424754] 
20. Mochizuki M, Kuwabara T, Chan CC, Nussenblatt RB, Metcalfe DD, Gery I. An association between susceptibility to experimental autoimmune uveitis and choroidal mast cell numbers. $\mathrm{J}$ Immunol. 1984; 133:1699-1701. [PubMed: 6332130]

21. Pennesi G, Caspi RR. Genetic control of susceptibility in clinical and experimental uveitis. Int Rev Immunol. 2002; 21:67-88. [PubMed: 12424837]

22. Agarwal RK, Chan CC, Wiggert B, Caspi RR. Pregnancy ameliorates induction and expression of experimental autoimmune uveitis. J Immunol. 1999; 162:2648-2654. [PubMed: 10072507]

23. Caspi RR, Chan CC, Grubbs BG, Silver PB, Wiggert B, Parsa CF, Bahmanyar S, Billiau A, Heremans H. Endogenous systemic IFN-gamma has a protective role against ocular autoimmunity in mice. J Immunol. 1994; 152:890-899. [PubMed: 8283058]

24. Silver PB, Chan CC, Wiggert B, Caspi RR. The requirement for pertussis to induce EAU is straindependent: B10.RIII, but not B10.A mice, develop EAU and Th1 responses to IRBP without pertussis treatment. Invest Ophthalmol Vis Sci. 1999; 40:2898-2905. [PubMed: 10549650]

25. Arimoto H, Tanuma N, Jee Y, Miyazawa T, Shima K, Matsumoto Y. Analysis of experimental autoimmune encephalomyelitis induced in $\mathrm{F} 344$ rats by pertussis toxin administration. $\mathrm{J}$ Neuroimmunol. 2000; 104:15-21. [PubMed: 10683510]

26. Ma RZ, Gao J, Meeker ND, Fillmore PD, Tung KS, Watanabe T, Zachary JF, Offner H, Blankenhorn EP, Teuscher C. Identification of Bphs, an autoimmune disease locus, as histamine receptor H1. Science. 2002; 297:620-623. [PubMed: 12142541]

27. Sudweeks JD, Todd JA, Blankenhorn EP, Wardell BB, Woodward SR, Meeker ND, Estes SS, Teuscher C. Locus controlling Bordetella pertussis-induced histamine sensitization (Bphs), an autoimmune disease-susceptibility gene, maps distal to T-cell receptor beta-chain gene on mouse chromosome 6. Proc Natl Acad Sci U S A. 1993; 90:3700-3704. [PubMed: 8475118]

28. Chen X, Howard OM, Oppenheim JJ. Pertussis toxin by inducing IL-6 promotes the generation of IL-17-producing CD4 cells. J Immunol. 2007; 178:6123-6129. [PubMed: 17475838]

29. Su SB, Silver PB, Wang P, Chan CC, Caspi RR. Dissociating the enhancing and inhibitory effects of pertussis toxin on autoimmune disease. J Immunol. 2003; 171:2314-2319. [PubMed: 12928376]

30. Su SB, Silver PB, Zhang M, Chan CC, Caspi RR. Pertussis toxin inhibits induction of tissuespecific autoimmune disease by disrupting G protein-coupled signals. J Immunol. 2001; 167:250256. [PubMed: 11418656]

31. Agarwal RK, Sun SH, Su SB, Chan CC, Caspi RR. Pertussis toxin alters the innate and the adaptive immune responses in a pertussis-dependent model of autoimmunity. J Neuroimmunol. 2002; 129:133-140. [PubMed: 12161029]

32. Caspi RR. Immunogenetic aspects of clinical and experimental uveitis. Reg Immunol. 1993; 4:321-330. [PubMed: 1290750]

33. Caspi RR, Roberge FG, Chan CC, Wiggert B, Chader GJ, Rozenszajn LA, Lando Z, Nussenblatt RB. A new model of autoimmune disease. Experimental autoimmune uveoretinitis induced in mice with two different retinal antigens. J Immunol. 1988; 140:1490-1495. [PubMed: 3346541]

34. Faure JP. Autoimmunity and the retina. Curr Top Eye Res. 1980; 2:215-301. [PubMed: 7344837]

35. Aronson SB, Hogan MJ, Zweigart P. Homoimmune uveitis in the guinea-pig. I. General concepts of auto- and homoimmunity, methods and manifestations. Arch Ophthalmol. 1963; 69:105-109.

36. Aronson SB, Hogan MJ, Zweigart P. Homoimmune uveitis in the guinea-pig. III. Histopathologic manifestations of the disease. Arch Ophthalmol. 1963; 69:208-219.

37. Aronson SB, Hogan MJ, Zweigart P. Homoimmune uveitis in the guinea-pig. II. Clinical manifestations. Arch Ophthalmol. 1963; 69:203-207.

38. Wacker WB, Kalsow CM. Autoimmune uveo-retinitis in the rat sensitized with retina photoreceptor cell antigen. Int Arch Allergy Appl Immunol. 1973; 45:582-592. [PubMed: 4583347]

39. de Kozak Y, Sakai J, Thillaye B, Faure JP. S antigen-induced experimental autoimmune uveoretinitis in rats. Curr Eye Res. 1981; 1:327-337. [PubMed: 6975701]

40. Gery I, Wiggert B, Redmond TM, Kuwabara T, Crawford MA, Vistica BP, Chader GJ. Uveoretinitis and pinealitis induced by immunization with interphotoreceptor retinoid-binding protein. Invest Ophthalmol Vis Sci. 1986; 27:1296-1300. [PubMed: 3488297] 
41. Caspi, R. Experimental autoimmune uveoretinitis (EAU) - mouse and rat. In: Kruisbeek, A.; Margulies, D.; Shevach, E.; Strober, W., editors. Current protocols in immunology. Wiley; New York, NY, USA: 1996 Jan. p. Unit 15.16.11-Unit 15.16.18.

42. Caspi, RR. Experimental autoimmune uveoretinitis: rat and mouse. In: Cohen, I.; Miller, A., editors. Autoimmune disease models: a guidebook. Academic; New York: 1994.

43. Mozayeni RM, Chan CC, Grubbs BE, Stober DI, Wiggert B, Chader GJ, Nussenblatt RB, Caspi RR. Alternative methods of immunization for the induction of experimental autoimmune uveoretinitis (EAU) in rodent models: a comparison. Ocul Immunol Inflamm. 1995; 3:81-87. [PubMed: 22827274]

44. Mochizuki M, Kuwabara T, McAllister C, Nussenblatt RB, Gery I. Adoptive transfer of experimental autoimmune uveoretinitis in rats. Immunopathogenic mechanisms and histologic features. Invest Ophthalmol Vis Sci. 1985; 26:1-9. [PubMed: 3967952]

45. Beraud E, Kotake S, Caspi RR, Oddo SM, Chan CC, Gery I, Nussenblatt RB. Control of experimental autoimmune uveoretinitis by low dose T cell vaccination. Cell Immunol. 1992; 140:112-122. [PubMed: 1739982]

46. Avichezer D, Silver PB, Chan CC, Wiggert B, Caspi RR. Identification of a new epitope of human IRBP that induces autoimmune uveoretinitis in mice of the $\mathrm{H}-2 \mathrm{~b}$ haplotype. Invest Ophthalmol Vis Sci. 2000; 41:127-131. [PubMed: 10634611]

47. Namba K, Ogasawara K, Kitaichi N, Matsuki N, Takahashi A, Sasamoto Y, Kotake S, Matsuda H, Iwabuchi K, Ohno S, Onoe K. Identification of a peptide inducing experimental autoimmune uveoretinitis (EAU) in H-2Ak-carrying mice. Clin Exp Immunol. 1998; 111:442-449. [PubMed: 9486417]

48. Silver PB, Rizzo LV, Chan CC, Donoso LA, Wiggert B, Caspi RR. Identification of a major pathogenic epitope in the human IRBP molecule recognized by mice of the H-2r haplotype. Invest Ophthalmol Vis Sci. 1995; 36:946-954. [PubMed: 7706044]

49. Cortes LM, Avichezer D, Silver PB, Luger D, Mattapallil MJ, Chan CC, Caspi RR. Inhibitory peptide analogs derived from a major uveitogenic epitope protect from anti-retinal autoimmunity by inducing type 2 and regulatory T cells. J Leukoc Biol. 2008; 84:577-585. [PubMed: 18495789]

50. Szpak Y, Vieville JC, Tabary T, Naud MC, Chopin M, Edelson C, Cohen JH, Dausset J, de Kozak Y, Pla M. Spontaneous retinopathy in HLA-A29 transgenic mice. Proc Natl Acad Sci U S A. 2001; 98:2572-2576. [PubMed: 11226280]

51. Pennesi G, Mattapallil MJ, Sun SH, Avichezer D, Silver PB, Karabekian Z, David CS, Hargrave PA, McDowell JH, Smith WC, Wiggert B, Donoso LA, Chan CC, Caspi RR. A humanized model of experimental autoimmune uveitis in HLA class II transgenic mice. J Clin Invest. 2003; 111:1171-1180. [PubMed: 12697736]

52. Axtell RC, de Jong BA, Boniface K, van der Voort LF, Bhat R, De Sarno P, Naves R, Han M, Zhong F, Castellanos JG, Mair R, Christakos A, Kolkowitz I, Katz L, Killestein J, Polman CH, de Waal MR, Steinman L, Raman C. T helper type 1 and 17 cells determine efficacy of interferonbeta in multiple sclerosis and experimental encephalomyelitis. Nat Med. 2010; 16:406-412. [PubMed: 20348925]

53. Domingues HS, Mues M, Lassmann H, Wekerle H, Krishnamoorthy G. Functional and pathogenic differences of Th1 and Th17 cells in experimental autoimmune encephalomyelitis. PLoS One. 2010; 5:e15531. [PubMed: 21209700]

54. Tang J, Zhu W, Silver PB, Su SB, Chan CC, Caspi RR. Autoimmune uveitis elicited with antigenpulsed dendritic cells has a distinct clinical signature and is driven by unique effector mechanisms: initial encounter with autoantigen defines disease phenotype. J Immunol. 2007; 178:5578-5587. [PubMed: 17442940]

55. Knapp JE, Liu D. Hydrodynamic delivery of DNA. Methods Mol Biol. 2004; 245:245-250. [PubMed: 14707385]

56. Chan CC, Caspi RR, Ni M, Leake WC, Wiggert B, Chader GJ, Nussenblatt RB. Pathology of experimental autoimmune uveo-retinitis in mice. J Autoimmun. 1990; 3:247-255. [PubMed: 2397018] 
57. Bjorck P. Isolation and characterization of plasmacytoid dendritic cells from Flt3 ligand and granulocyte-macrophage colony-stimulating factor-treated mice. Blood. 2001; 98:3520-3526. [PubMed: 11739152]

58. Vremec D, Pooley J, Hochrein H, Wu L, Shortman K. CD4 and CD8 expression by dendritic cell subtypes in mouse thymus and spleen. J Immunol. 2000; 164:2978-2986. [PubMed: 10706685]

59. Donoso LA, Yamaki K, Merryman CF, Shinohara T, Yue S, Sery TW. Human S-antigen: characterization of uveitopathogenic sites. Curr Eye Res. 1988; 7:1077-1085. [PubMed: 2468448]

60. Singh VK, Nussenblatt RB, Donoso LA, Yamaki K, Chan CC, Shinohara T. Identification of a uveitopathogenic and lymphocyte proliferation site in bovine S-antigen. Cell Immunol. 1988; 115:413-419. [PubMed: 2457449]

61. Donoso LA, Merryman CF, Sery TW, Shinohara T, Dietzschold B, Smith A, Kalsow CM. Santigen: characterization of a pathogenic epitope which mediates experimental autoimmune uveitis and pinealitis in Lewis rats. Curr Eye Res. 1987; 6:1151-1159. [PubMed: 2444394]

62. Kotake S, Redmond TM, Wiggert B, Vistica B, Sanui H, Chader GJ, Gery I. Unusual immunologic properties of the uveitogenic interphotoreceptor retinoid-binding protein-derived peptide R23. Invest Ophthalmol Vis Sci. 1991; 32:2058-2064. [PubMed: 2055698]

63. Sanui H, Redmond TM, Hu LH, Kuwabara T, Margalit H, Cornette JL, Wiggert B, Chader GJ, Gery I. Synthetic peptides derived from IRBP induce EAU and EAP in Lewis rats. Curr Eye Res. 1988; 7:727-735. [PubMed: 3262040]

64. Kotake S, de Smet MD, Wiggert B, Redmond TM, Chader GJ, Gery I. Analysis of the pivotal residues of the immunodominant and highly uveitogenic determinant of interphoto-receptor retinoid-binding protein. J Immunol. 1991; 146:2995-3001. [PubMed: 1707928]

65. de Smet MD, Bitar G, Roberge FG, Gery I, Nussenblatt RB. Human S-Antigen: Presence of multiple immunogenic and immunopathogenic sites in the Lewis rat. J Autoimmun. 1993; 6:587599. [PubMed: 7694588]

66. Merryman CF, Donoso LA, Zhang XM, Heber-Katz E, Gregerson DS. Characterization of a new, potent, immunopathogenic epitope in S-antigen that elicits $\mathrm{T}$ cells expressing $\mathrm{V}$ beta 8 and $\mathrm{V}$ alpha 2-like genes. J Immunol. 1991; 146:75-80. [PubMed: 1701801]

67. Gregerson DS, Merryman CF, Obritsch WF, Donoso LA. Identification of a potent new pathogenic site in human retinal S-antigen which induces experimental autoimmune uveo-retinitis in LEW rats. Cell Immunol. 1990; 128:209-219. [PubMed: 2344622]

68. Donoso LA, Merryman CF, Sery T, Sanders R, Vrabec T, Fong SL. Human interstitial retinoid binding protein. A potent uveitopathogenic agent for the induction of experimental autoimmune uveitis. J Immunol. 1989; 143:79-83. [PubMed: 2786534]

69. Horai, R.; Caspi, RR., editors. Neuromethods. Vol. 46. Humana; New York, NY: 2010. Retinal inflammation: uveitis/uveoretinitis. Animal models for retinal diseases.

70. Mattapallil MJ, Wawrousek EF, Chan CC, Zhao H, Roychoudhury J, Ferguson TA, Caspi RR. The $\mathrm{rd} 8$ mutation of the $\mathrm{Crb} 1$ gene is present in vendor lines of C57BL/6N mice and embryonic stem cells, and confounds ocular induced mutant phenotypes. Invest Ophthalmol Vis Sci. 2012 in press. 

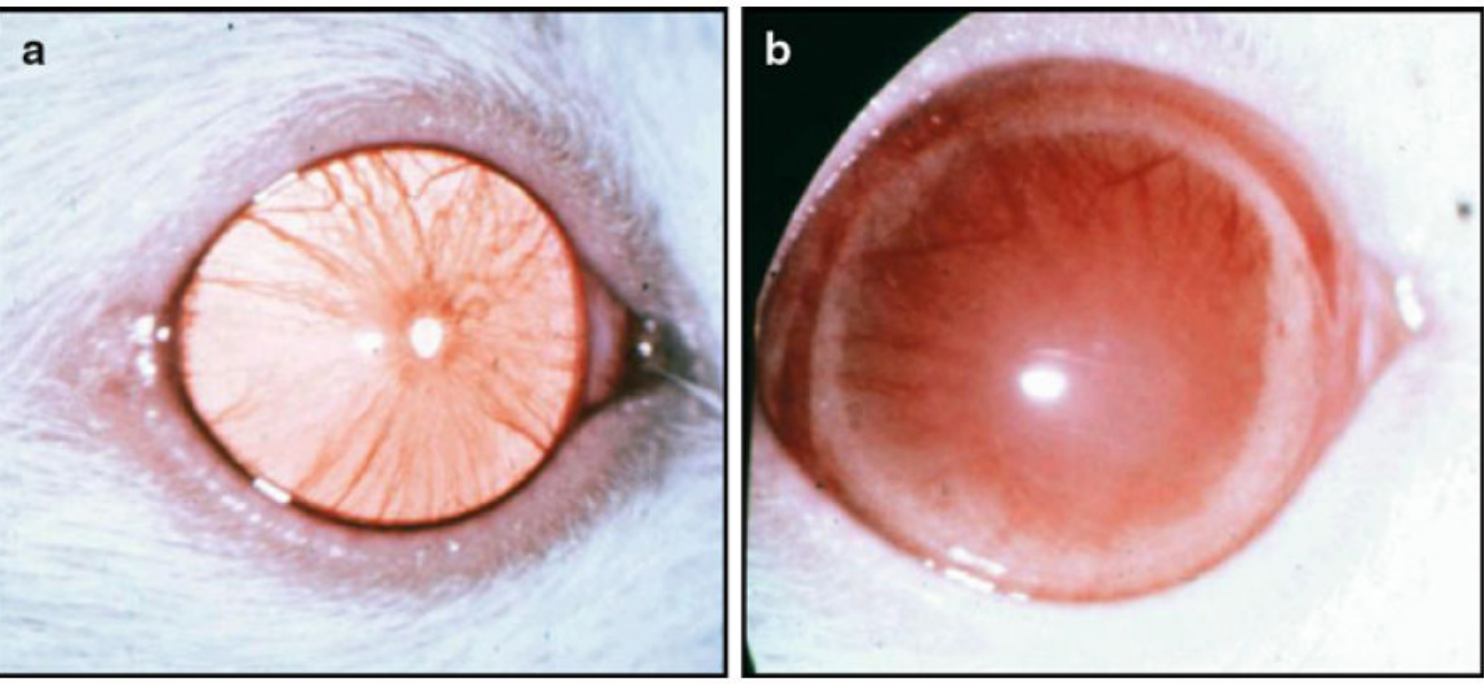

Fig. 1.

Clinical appearance of EAU in the Lewis rat by anterior chamber examination. (a) Normal eye; translucent appearance; pupil and iris blood vessels are clearly visible and the vessels are not congested. (b) Uveitic eye; the eye appears larger due to swelling and proptosis; red reflex is absent and pupil is obscured. 

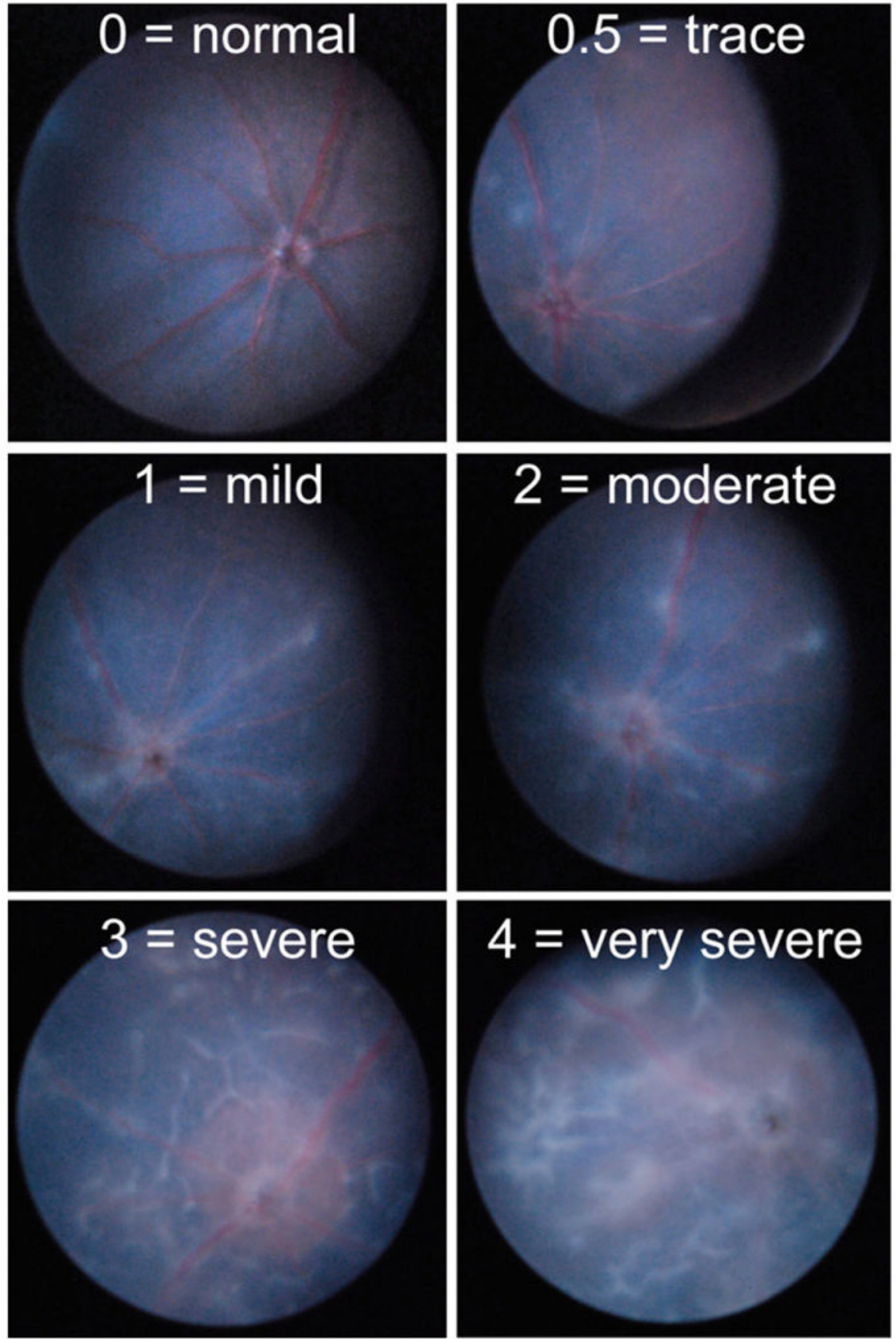

Fig. 2.

Clinical appearance of EAU in the B10.RIII mouse by fundoscopic exam. Eyes were photographed with a fundus camera during the acute phase of disease (day 14-21). The range of disease severity scores parallel the pathological scores in Fig. 3. (Figure adapted from reference 69). 

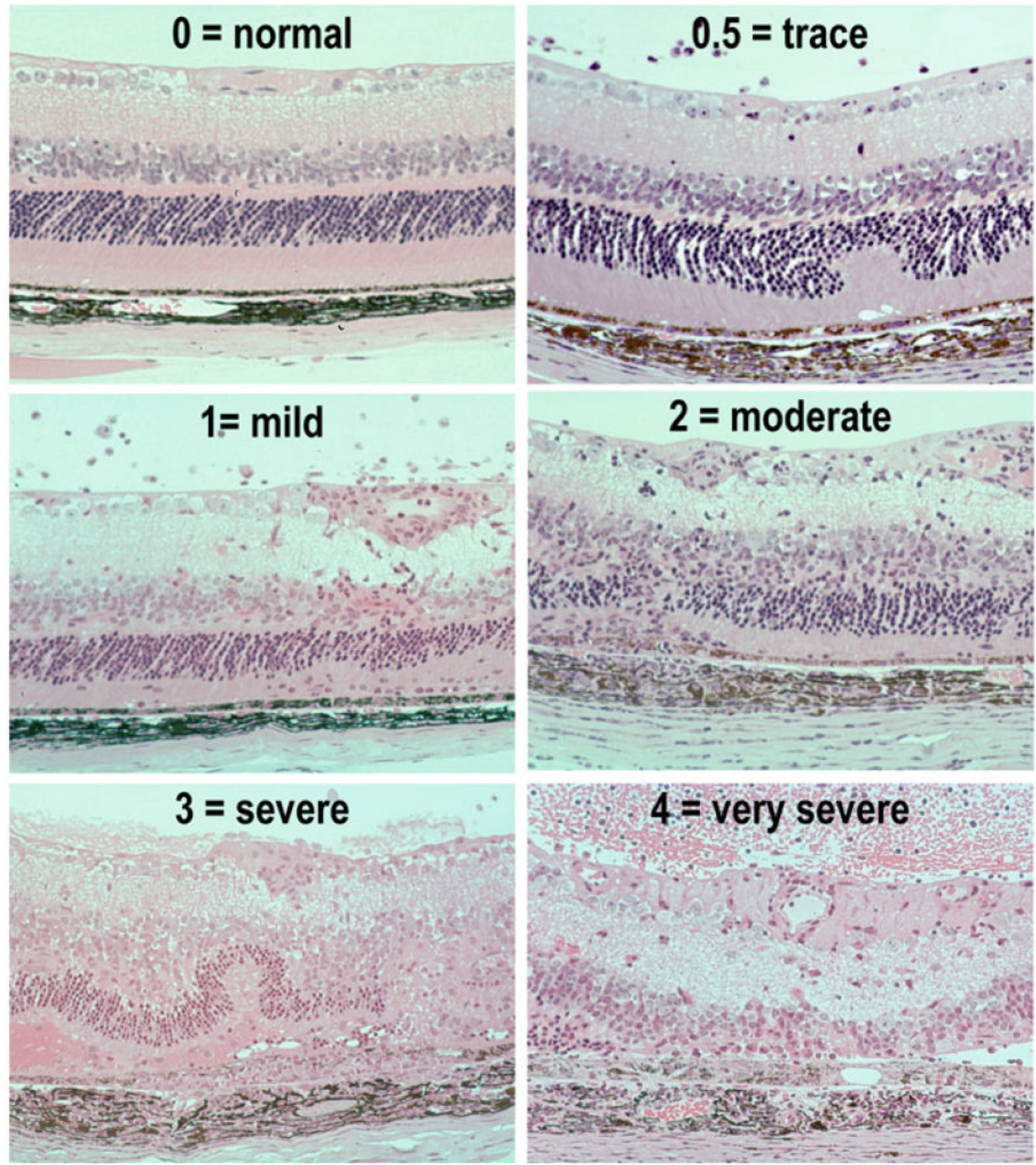

Fig. 3.

Histopathology of EAU in the B10.RIII mouse. Eyes were collected from B10.RIII mice 21 days after uveitogenic immunization with IRBP, representing a range of disease scores. (Figure adapted from references 49, 69). EAU in the rat shows essentially the same type of histopathology. 


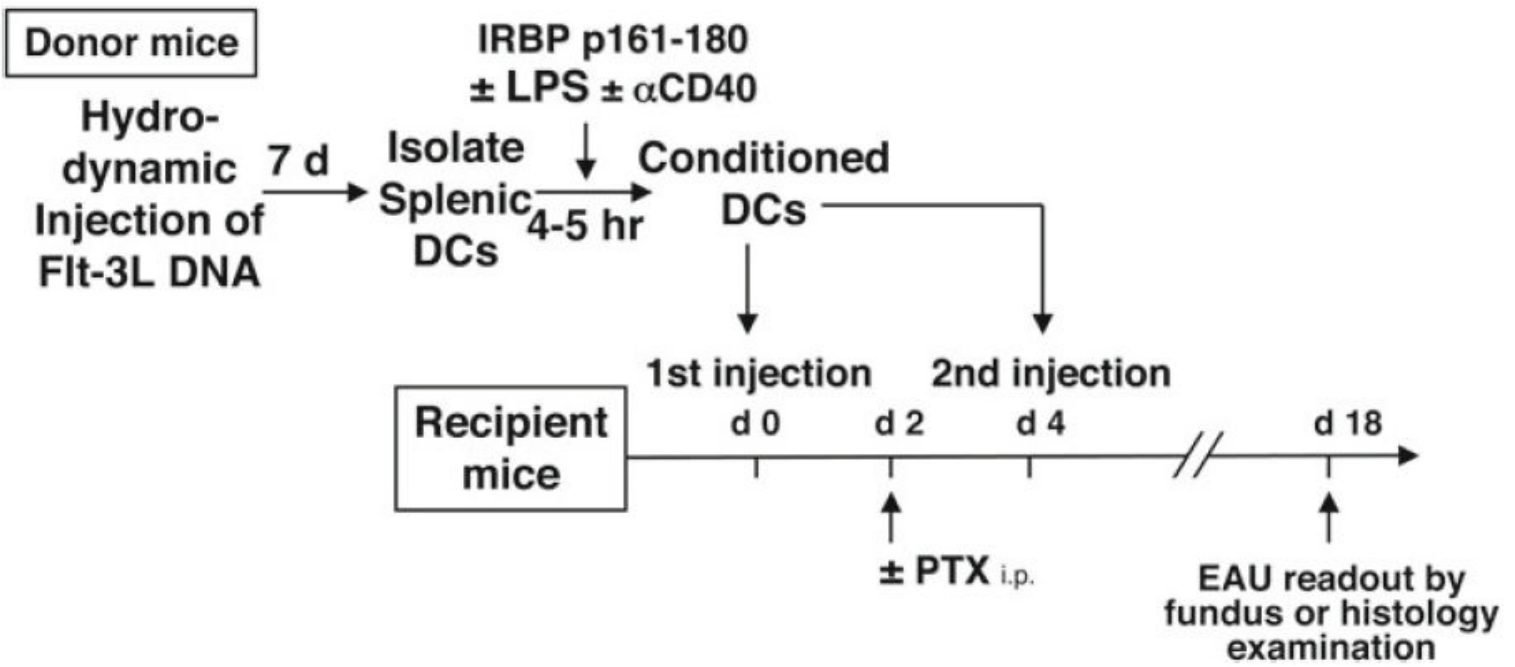

Fig. 4.

Protocol for induction of autoimmune uveitis in B10.RIII mice with antigen-pulsed DCs (54). 
Table 1

Susceptibility to EAU of some inbred rat strains ${ }^{a}$

\begin{tabular}{|c|c|c|c|c|}
\hline Strain & MHC & Susceptibility & Antigen & Reference \\
\hline Lewis & $\mathrm{RT} 1^{1}$ & High & S-Ag, IRBP & $(3,19)$ \\
\hline F344 & RT1 ${ }^{\text {lv1 }}$ & Low & S-Ag, IRBP peptide R16 & $(3,19,31)$ \\
\hline $\mathrm{CAR}^{b}$ & $\mathrm{RT}^{1}{ }^{1}$ & High & S-Ag & $(3,19)$ \\
\hline $\mathrm{BN}$ & $\mathrm{RT}^{\mathrm{n}}$ & Low $^{c}$ & S-Ag & (5) \\
\hline PVG & $\mathrm{RT}^{c}{ }^{c}$ & High & S-Ag & (39) \\
\hline
\end{tabular}

${ }^{a}$ Please see other references for more detailed list $(41,42)$

$b_{\text {Resistance of this strain may vary in different colonies (19) }}$

$c_{\text {Resistance is not overcome by PTX treatment }}$ 
Table 3

Clinical grading of EAU in the rat

\begin{tabular}{ll} 
Grade $^{\boldsymbol{a}}$ & Criteria \\
\hline 0 & No disease; eye is translucent and reflects light (red reflex) \\
\hline 0.5 (trace) & Dilated blood vessels in the iris \\
\hline 1 & Engorged blood vessels in iris; abnormal pupil contraction \\
\hline 2 & Hazy anterior chamber; decreased red reflex \\
\hline 3 & Moderately opaque anterior chamber, but pupil still visible; dull red reflex \\
\hline 4 & Opaque anterior chamber and obscured pupil; red reflex absent; proptosis \\
\hline
\end{tabular}

${ }^{a}$ Each higher grade includes the criteria of the preceding one 
Table 4

Scoring EAU histopathologically in the rat

\begin{tabular}{lll} 
Grade & Area of retinal section affected & Criteria \\
\hline 0 & None & No disease, normal retinal architecture \\
\hline 0.5 (trace) & $<1 / 4$ & Mild inflammatory cell infiltration of the retina with or without photoreceptor damage \\
\hline 1 & $\geq 1 / 4$ & Mild inflammation and/or photoreceptor outer segment damage \\
\hline 2 & $\geq 1 / 4$ & Mild to moderate inflammation and/or lesion extending to the outer nuclear layer \\
\hline 3 & $\geq 1 / 4$ & Moderate to marked inflammation and/or lesion extending to the inner nuclear layer \\
\hline 4 & $\geq 1 / 4$ & Severe inflammation and/or full-thickness retinal damage \\
\hline
\end{tabular}


Table 5

Susceptibility of different mouse strains to IRBP-EAU ${ }^{a}$

\begin{tabular}{|c|c|c|c|}
\hline Strain & $\mathbf{H}-2$ & Expected disease score & Epitope, position, and reference \\
\hline \multirow[t]{3}{*}{ B10.RIII } & $\mathrm{r}$ & Very high & SGIPYIISYLHPGNTILHVD $\left(161-180^{b}\right)(48)$ \\
\hline & & Medium & HPGNTILHVDTIYNRPSNTT (171-190) (49) \\
\hline & & Medium & SLGWATLVGEITAGNLLHTR (541-560) (49) \\
\hline B10.A & $\mathrm{a}\left(\mathrm{I}-\mathrm{A}^{\mathrm{k}}\right)$ & High & ADKDVVVLTSSRTGGV (201-216) (47) \\
\hline B10.BR & $\mathrm{k}$ & High & Same as B10.A \\
\hline $\mathrm{A} / \mathrm{J}$ & $\mathrm{a}\left(\mathrm{I}-\mathrm{A}^{\mathrm{k}}\right)$ & Medium & Same as B10.A \\
\hline \multirow[t]{3}{*}{$\mathrm{C} 57 \mathrm{BL} / 6$} & $\mathrm{~b}$ & Moderate & GPTHLFQPSLVLDMAKVLLD (1-20) (46) \\
\hline & & Moderate & LRHNPGGPSSAVPLLLSYFQ (461-480) (49) \\
\hline & & Moderate & LAQGAYRTAVDLESLASQLT (651-670) (49) \\
\hline $\mathrm{C} 57 \mathrm{BL} / 10$ & $\mathrm{~b}$ & Medium & Same as C57BL/6 \\
\hline
\end{tabular}

${ }^{a}$ More detailed list of other mouse strains can be found elsewhere (41)

$b_{\text {Human sequence. PT is not required }}$ 
Table 6

Clinical scoring of EAU in the mouse

\begin{tabular}{ll} 
Grade & Criteria \\
\hline 0 & No change \\
\hline 0.5 (trace) & Few (1-2) very small, peripheral focal lesion; minimal vasculitis/vitritis \\
\hline 1 & Mild vasculitis; <5 small focal lesions; $\leq$ linear lesion \\
\hline 2 & $\begin{array}{l}\text { Multiple (>5) chorioretinal lesions and/or infiltrations; severe vasculitis (large size, thick wall, infiltrations); few linear lesions } \\
(<5)\end{array}$ \\
\hline 3 & Pattern of linear lesions; large confluent lesions; subretinal neovascularization; retinal hemorrhages; papilledema \\
\hline 4 & Large retinal detachment; retinal atrophy \\
\hline
\end{tabular}


Table 7

Grading EAU histopathologically in the mouse

\begin{tabular}{ll} 
Grade & Criteria \\
\hline 0 & No change \\
\hline 0.5 (trace) & Mild inflammatory cell infiltration. No tissue damage \\
\hline 1 & Infiltration; retinal folds and focal retinal detachments; few small granulomas in choroid and retina, perivasculitis \\
\hline 2 & $\begin{array}{l}\text { Moderate infiltration; retinal folds, detachments and focal photoreceptor cell damage; small to medium sized granulomas, } \\
\text { perivasculitis and vasculitis }\end{array}$ \\
\hline 3 & $\begin{array}{l}\text { Medium to heavy infiltration; extensive retinal folding with detachments, moderate photoreceptor cell damage; medium sized } \\
\text { granulomatous lesions; subretinal neovascularization }\end{array}$ \\
\hline 4 & $\begin{array}{l}\text { Heavy infiltration; diffuse retinal detachment with serous exudate and subretinal bleeding; extensive photoreceptor cell damage; } \\
\text { large granulomatous lesions; subretinal neovascularization }\end{array}$ \\
\hline
\end{tabular}

